\title{
The Effect of Peer-Support to Students' Academic Stress in Boarding School with House System
}

\author{
Muhammad Rizkita \\ Departement of Theology and Islamic Thoughts, Faculty of Theology and Islamic Philosophy, UIN Sunan Kalijaga, \\ Jl. Marsda Adisucipto No. 1 Yogyakarta 55281, Indonesia. Phone. +62-853-3102-2640. \\ Email: rizkta25r@gmail.com
}

\begin{abstract}
The purpose of this research is to describe the level of academic stress and peer-support among students; in boarding school with house system; and to analyze the role of peer-support to students' academic stress in boarding school with house system. Peersupport is measured by Child and Adolescent Social Support Scale-Academic (CASSS-A) with Cronbach $\alpha=.97$ (Sonia, 2014) as an independent variable and academic stress is measured by Educational Stress Scale for Adolescents (ESSA) with Cronbach $\alpha=.82$ (Sun, 2012) as a dependent variable. Data collection was carried out at SMAN Sumatera Selatan as one one of boarding school that implements a house system in Indonesia with 60 out of 300 students as a sample in this research. Researchers use a cluster sampling technique. The result of this research shows that peer-support is on an average level; academic stress is on an average level that analyze by descriptive analysis technique. Simple linear analysis techniques are used as inferential analysis which shows that there is no effect of peer-support to students' academic stress in a boarding school with house system, in other words, Ha in this research is accepted. As the researcher evaluated the result of this research, self-efficacy found as a mediator variable between social support (peer support, parent support, and teacher support) to students' academic stress in a boarding school with house system and become a recommendation for upcoming research
\end{abstract}

Keywords: Academic stress, boarding school, house system, peer support.

Abbreviations: House system (HS)

\section{INTRODUCTION}

Early adolescents are crucial development stages of humans. This stage displays massive cognitive, social, emotional and physical changes. This developmental shock often has implications for the onset of the phenomenon of stress in adolescents. Stress is defined as a condition when psychological aspects suppress a person's ability to adapt (Lazarus, 1996: Lazarus and Folkman, 1984; Zajacova, Lynch \& Espenshade, 2005). Kaushal (2018) stated that academic stress is the main factor that causes adolescent stress. Stress that is not properly handled will interfere with academic ability and increase the likelihood of being involved in rapid behavior such as drug abuse and other destructive behavior (Strubbe, 1989)

There are five stressors that trigger Academic stress that may come from academic stressor which is worried about the future, a lot of homework, situation in the class, a rank, examination, and other people's expectations (Sun, 2012). A student who lived in boarding school there is some additional academic stressors that should be faced by students which are, the changes that occur in the school environment; living in dormitories; new teachers and friends; and pressure from rules and rhythm of dorm life.

One of the factors that influence adolescents' abilities to deal with academic stress is social support, which support from family becomes primary support, as Fisher at al (1986) said for a person who leaves home to reside in a new place for educational reasons both aspects may be influential. Which there is distancing from the support normally given by family and friends; loss a familiar "routine" pattern of life and exposure to an implosion of new environmental and psychological factors and the need to adjust to change in residence resulting in loss of direct contact with family and with the home environment. For students who lived in boarding school, there is others social support source that come from teachers and peers (Sun, 2012) in this study, researchers investigated social support from peers.

House system (HS) is a unique-boarding school concept that adapted from England. Students on HSboarding school are separated into a different group called "house", the main purpose of this concept is to make school having a "home base" situation (Dieferenfied, 1976). SMAN Sumatera Selatan as one of school in Indonesia who is implementing HS concept divided students into small house which are, Dolphin house, Dove house, Eagle house, Hornbill house, Komodo house, Lion house, Mantaray house, Rhino house, and Shark House which is expected to help student give support between them to cope with stress. Students will live together in the same dormitory for three years of study and provided by many activities that will strengthen their bonding as a family in the 
dormitory. Those activities such as house gather, house cooking, house assembly, house point card, and many others. In this study the researcher tried to examined whether grouping students with house systems can affect the students ability to dealing with academic stress

\section{MATERIALS AND METHODS}

This research used quantitative non-experiment research methods with random sampling technique. The research is placed in SMAN Sumatera Selatan with 60 students out of 300 as sample. The data collected by questionnaire that adapted Child and Adolescent Social Support Scale-Academic (CASSS-A) that build up by Sonia S. (2014) and Educational Stress Scale for Adolescents (ESSA) for dependent variable from Sun (2012). The results examined with descriptive analysis and simple linear regression for inferential analysis. Desriptive analysis and hypothesis testing were carried out using Statistical Package for Social Science (SPPSS) based on field study.

\section{RESULTS AND DISCUSSION}

\section{Result 1 - Desciptive Analysis Results Peer Support (Child and Adolescents Social Support Scale- Academic) \\ Respondent of this research is 60 students and classified based on grade, sex, and major.}

Table 1. Description of peer support by CASSS-A.

\begin{tabular}{|c|c|c|c|c|c|}
\hline \multicolumn{2}{|c|}{ Aspect } & $\begin{array}{l}\text { Number of } \\
\text { respondent }\end{array}$ & $\begin{array}{c}\text { Percentage } \\
(\%)\end{array}$ & $\begin{array}{c}\text { Mean } \\
\text { CASSS- } \\
\text { A }\end{array}$ & $\begin{array}{c}\text { SD } \\
\text { CASSS- } \\
\text { A }\end{array}$ \\
\hline \multirow[t]{3}{*}{ Grade } & 10 & 18 & 30 & 45,66 & 10,63 \\
\hline & 11 & 18 & 30 & 50,66 & 11,59 \\
\hline & 12 & 24 & 40 & 48,66 & 7,92 \\
\hline \multicolumn{2}{|c|}{ total } & 60 & 100 & 48,26 & $\mathbf{9 , 9 7}$ \\
\hline \multirow[t]{2}{*}{ Sex } & Male & 30 & 50 & 49.43 & 9,26 \\
\hline & Female & 30 & 50 & 47,10 & 10,67 \\
\hline \multicolumn{2}{|c|}{ Total } & 60 & 100 & 48,66 & $\mathbf{9 , 8 8}$ \\
\hline \multirow[t]{2}{*}{ Major } & $\begin{array}{c}\begin{array}{c}\text { Natural } \\
\text { science }\end{array} \\
\end{array}$ & 39 & 65 & 45,06 & 8,74 \\
\hline & $\begin{array}{c}\text { Social } \\
\text { Science }\end{array}$ & 21 & 35 & 46,00 & 8,44 \\
\hline
\end{tabular}

$C A S S S-A=C h i l d$ and Adolescents Social Support Scale-Academic; Mean= average value; $S D=$ Standard deviation;

a. Based on grade, results shows theoretical average value of CASSS-A on $(\mu=48)$ and $10(\mu=45,66) ; 11$ $(\mu=50,66) ; 12(\mu=48,66)$.

b. Based on sex, results shows theoretical average value on CASSS-A on $(\mu=48,26)$ and male $(\mu=49.48)$; female $(\mu=47,48)$.

c. Based on major, results shows theoretical average value on CASSS-A on $(\mu=48)$ and natural science $(\mu=48,66)$ Social science $(\mu=47,52)$
Table 2. Description of peer support by ESSA.

\begin{tabular}{|c|c|c|c|c|c|}
\hline \multicolumn{2}{|c|}{ Aspect } & $\begin{array}{l}\text { Number of } \\
\text { respondent }\end{array}$ & $\begin{array}{c}\text { Percentage } \\
(\%)\end{array}$ & $\begin{array}{l}\text { Mean } \\
\text { ESSA }\end{array}$ & $\begin{array}{c}\text { SD } \\
\text { ESSA }\end{array}$ \\
\hline \multirow[t]{3}{*}{ Grade } & 10 & 18 & 30 & 42,22 & 8,69 \\
\hline & 11 & 18 & 30 & 50 & 9,08 \\
\hline & 12 & 24 & 40 & 42,83 & 6,89 \\
\hline \multicolumn{2}{|c|}{ total } & 60 & 100 & 45,40 & 8,58 \\
\hline \multirow[t]{2}{*}{ Sex } & Male & 30 & 50 & 44,36 & 9,62 \\
\hline & Female & 30 & 50 & 46,43 & 7,41 \\
\hline \multicolumn{2}{|c|}{ Total } & 60 & 100 & 45,40 & 8,58 \\
\hline \multirow[t]{3}{*}{ Major } & $\begin{array}{l}\text { Natural } \\
\text { science }\end{array}$ & 39 & 65 & 45,06 & 8,74 \\
\hline & $\begin{array}{l}\text { Social } \\
\text { Science }\end{array}$ & 21 & 35 & 46,00 & 8,44 \\
\hline & tal & 60 & 100 & 45,40 & 8,58 \\
\hline
\end{tabular}

$E S S A=$ Educational Stress Scale for Adolescents; Mean= average value; $S D=$ Standard deviation;

a. Based on grade, results shows theoretical average value of CASSS-A on $(\mu=45,40)$ and $10(\mu=42,83)$; $11(\mu=50) ; 12(\mu=42,83)$.

b. Based on sex, results shows theoretical average value on CASSS-A on $(\mu=45,40)$ and male $(\mu=46.40)$; female $(\mu=44,36)$.

c. Based on major, results shows theoretical average value on CASSS-A on $(\mu=48)$ and natural science $(\mu=48,66)$ Social science $(\mu=47,52)$

Table 3. level of peer support by CASSS-A.

\begin{tabular}{lllll}
\hline & Frequency & Percent & $\begin{array}{l}\text { Valid } \\
\text { percent }\end{array}$ & $\begin{array}{l}\text { Cumulative } \\
\text { percent }\end{array}$ \\
\hline High & 11 & 18,3 & 18,3 & 18,3 \\
Moderate & 38 & 63 & 63 & 81,7 \\
Low & 11 & 18,3 & 18,3 & 18,3 \\
Total & 60 & 100 & 100 & \\
\hline
\end{tabular}

Based on the results of frequency analysis shows 11 respondent received high level of social support (peer support); 38 respondent on moderate level; 11 respondent on low level.

Table 4. level of academic stress by ESSA.

\begin{tabular}{lllll}
\hline & Frequency & Percent & $\begin{array}{l}\text { Valid } \\
\text { percent }\end{array}$ & $\begin{array}{l}\text { Cumulative } \\
\text { percent }\end{array}$ \\
\hline High & 12 & 20 & 20 & 20.0 \\
Moderate & 39 & 65 & 65 & 85 \\
Low & 9 & 15 & 15 & 100 \\
Total & 60 & 100 & 100 & \\
\hline
\end{tabular}

Based on the results of frequency analysis shows 12 respondent is experienced high level of academic stress;39 respondent on moderate level; 9 respondent on low level.

Result 2 - Inferential Analysis Results Peer Support (Child and Adolescents Social Support ScaleAcademic)

Researcher used a simple regression method to evaluate the effect of variables $(\mathrm{X})$ peer support to variable $(\mathrm{Y})$ academic stress. The following are the results obtained. 
Table 5. Inferential Analysis peer support (X) to academic stress.

\begin{tabular}{|c|c|c|c|c|c|c|c|}
\hline ESSA & $\mathrm{R}$ & $\mathrm{R}^{2}$ & $\begin{array}{l}\text { Adjust } \\
\text { ed } R^{2}\end{array}$ & $\mathrm{~B}^{*}$ & $\mathrm{~B}^{* *}$ & $\mathrm{t}$ & Sig. \\
\hline Model & $.009^{\mathrm{a}}$ & .000 & -.017 & & & & \\
\hline $\begin{array}{l}\text { Summary } \\
\text { (constant) }\end{array}$ & & & & 45,042 & & 8.097 & .000 \\
\hline CASSS-A & & & & .007 & .009 & .066 & .948 \\
\hline
\end{tabular}

Results on table 5 about analysis of the correlation coefficient between peer support to students' academic stress demonstrates the value of significant $\mathrm{p}=.948$ $(\mathrm{p}>0,05)$ means hypothesis alternative $(\mathrm{Ha})$ is rejected and hypothesis null (H0) is accepted. Based on $\mathrm{r}$ value show very low contribution of peer support to students' academic stress, .009 or $0,9 \%$. Yprim $=45.042+0,007+$ e.

\section{Discussion}

This results totally different from early research done by Nokawoska (2014) and Wang \& Yeh (on Santrock, 2007) that identified peer support (or friends support) could be another source of social support out of parents that help adolescents cope with academic stress. This results surprisingly different from early research done by Nokawoska (2014) and Wang \& Yeh (on Santrock, 2007) that identified peer support (or friends support) could be another source of social support out of parents that help adolescents cope with academic stress. This is antithesis results surprisingly happened on boarding school with a house system that predicted to be an ideal atmosphere for social support to be built. More detail Sulivian (1953) and Pieget (1932) said that peer groups provide positif influence for adolescents and will mature adolescents personality while it is on line with house system boarding school concept that devided them into a small group that called by 'house'.

As the researcher tried to evaluate this result, selfefficacy found as a moderator variable that connecting peer support to students' ability to cope with academic stress. Krystle (2017) found self-efficacy as the main factor that having a direct influence on the level of academic stress. Furthermore, based on research done by Kaushal et. al (2019) divided two copping stress source ability. First, coping ability source that comes from adolescents itself trough their self-efficacy and coping ability source that comes from external, which is social support. Krystle (2017) found adolescents with low selfefficacy tend to experiences a high level of academic stress even though has high perceived social support level.

\section{CONCLUSION}

Based on data analysis, found that, alleged by researchers that there is an influence between peer support for academic stress is not proven; The description of academic stress in SMAN Sumatera Selatan is 12 people students experience stress in the high range, 39 students in the medium range and 9 students in a low range; The description of peer support in SMAN Sumatera Selatan which is 11 students felt that they received peer support in the high range, 38 students in the medium range, and 11 students in the low range.

The findings suggest that there was no effect between peer support on academic stress in schools that implemented a house system in contrast to previous studies conducted in conventional boarding schools. This needs to be interestingto study further by including selfefficacy as a moderator variable. Also, the scope of social support needs to be expanded. The role of house parent is also ideal to be explored as a source of social support in place of parents

\section{ACKNOWLEDGEMENTS}

I'm deeply indebted to my supervisor, Mrs. Deshinta Vibriyanti, as a researcher in Indonesian Institute of Science for warm support, inspiration and thoughtful guidance. Special thanks to Mrs. Fina for her help on data analysis, also I wish my to expres my deep thanks to all the members of SMAN Sumatera Selatan for their kindness and helps to be respondent for this research.

\section{REFERENCES}

Copeland, Ellis P., dan Robyn S. Hess. "Differences in Young Adolescents' Coping Strategies Based On Gender and Ethnicity." The Journal of Early Adolescence 15, no. 2 (Mei 1995):

203-19. https://doi.org/10.1177/0272431695015002002.

Fisher, Shirley, Norman Frazer, dan Keith Murray. "Homesickness and Health in Boarding School Children." Journal of Environmental Psychology 6, no. 1 (Maret 1986): 35-47. https://doi.org/10.1016/S0272-4944(86)80033-0.

Jerrold S. Greenberg. Comprehensive Stress Management. 9 ed. New York: Wiliam Glass, 2006.

Jhon W. Santrock. REMAJA. Penerbit Eirlangga, 2007.

Kaushal, Yashovardhan, Sunita Koreti, dan Ajay Gaur. "Educational stress and coping strategies in school going adolescents." International Journal of Contemporary Pediatrics 5, no. 4 (22 Juni 2018): 1452. https://doi.org/10.18203/2349-3291.ijcp20182545.

Khan, Mussarat Jabeen, Seema Altaf, dan Hafsa Kausar. "Effect of Perceived Academic Stress on Students' Performance," 2013, 7

Locke, Edwin A., Elizabeth Frederick, Cynthia Lee, dan Philip Bobko. "Effect of Self-Efficacy, Goals, and Task Strategies on Task Performance.” Journal of Applied Psychology 69, no. 2 (1984): 241-51. https://doi.org/10.1037/0021-9010.69.2.241.

Nowakowska, Sonia S. “Measuring Adolescents' Perceptions of Academic Social Support: The Relationship Between Academic Social Support, Global Social Support, And Level of Functioning," 2014, 132. 
R. B Dierenfield. "Personalizing Education: The House System in England." Phi Delta Kappa International 56 (1985): 605-7.

Strubbe, Mary A. "An Assessment of Early Adolescent Stress Factors." Middle School Research Selected Studies 14, no. 1 (Januari 1989): 47-59. https://doi.org/10.1080/08851700.1989.11670300.

Sun, Jiandong, Michael P. Dunne, Xiang-yu Hou, dan Ai-qiang $\mathrm{Xu}$. "Educational Stress among Chinese Adolescents: Individual, Family, School and Peer Influences.” Educational
Review 65, no. 3 (Agustus 2013): 284-302. https://doi.org/10.1080/00131911.2012.659657

Syah, M. Psikologi Belajar. Raja Grafindo Persada, 2003.

Widiastono. "Sekolah Berasrama: Ketika Jakarta tak Lagi Dirasa Nyaman. Diambil kembali dari.” Kompas.com, Agustus 2001. 